\title{
EverGraze - a project to achieve profit and environmental outcomes in the Australian grazing industries
}

\author{
M.A. Friend ${ }^{1,4,5}$, S. Robertson ${ }^{1,4}$, D. Masters ${ }^{2,4}$ and A. Avery ${ }^{3,4}$ \\ ${ }^{1}$ EH Graham Centre for Agricultural Innovation, Charles Sturt University \\ and NSW Department of Primary Industries \\ Locked Bag 588, Wagga Wagga, NSW 2678, Australia \\ ${ }^{2}$ CSIRO Livestock Industries \\ Private Bag 5, Wembley, WA 6913, Australia \\ ${ }^{3}$ Primary Industries Research Victoria \\ RMB 1145, Rutherglen, Vic 3685, Australia \\ ${ }^{4}$ Co-operative Research Centre for Plant-based Management of Dryland Salinity, \\ University of Western Australia \\ 35 Stirling Highway, Crawley, WA 6009, Australia
}

\begin{abstract}
Australian agriculture is faced with environmental issues including increasing land and river salinity and reduced biodiversity. Key to the addressing these are to develop livestock systems that achieve improved environmental outcomes and increased profit, in order to promote widespread adoption. EverGraze is a national research and extension project developing innovative livestock production systems based on perennial pastures which will deliver improved profit and environmental outcomes. Integrated bioeconomic and biophysical modeling (in consultation with farmers and catchment managers) was used to identify farming systems which have the potential to deliver improved profit and environmental outcomes, as well as identifying constraints to achieving these outcomes. Whole farm systems and component research is now underway across several sites in the high rainfall zones $(>550 \mathrm{~mm})$ of southern Australia to test the potential of new livestock systems and to investigate the specific benefits of parts of these systems (e.g., improving sheep reproductive performance through perennial pastures and shrubs). This paper presents modelling results and how they were used to design field experiments, and preliminary experimental results from one of these experiments.
\end{abstract}

KEY WORDS: livestock, profit, environment, perennial pastures

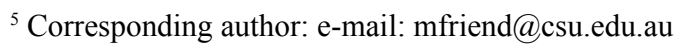




\section{INTRODUCTION}

Salinity threatens vast areas of southern Australia; in western Australia alone the most recent estimates are that nearly 1 million ha are affected (Macfarlane et al., 2004). Much of the increase in salinity is attributed to the replacement of native perennial vegetation with annual pasture and crop systems which permit substantial leakage of fresh water into the deep aquifers, causing a rise in saline water tables. While much of this land is capable of growing a range of salt tolerant plants, many of which have value as livestock feed and delay the spread of salinity, the real challenge is to encourage the broad-scale adoption of perennial pasture or crop systems (particularly those with summer activity) which will reduce water leakage below the root zone (or groundwater recharge), thus reducing the spread of dryland salinity.

'EverGraze' is a national research and delivery project which is investigating livestock systems based on perennial pastures in areas that contribute significantly to groundwater recharge. This paper describes the EverGraze project and its novel approach to increasing profit while addressing environmental issues facing Australian agriculture, using computer modelling data and preliminary field data from one of the research sites as an example.

\section{THE ROLE OF MODELLING IN EVERGRAZE}

While the use of perennial species that use more water than annuals is an option available in the management of water on-farm and within catchments in the high rainfall zone (greater than $550 \mathrm{~mm} /$ year), the challenge is to achieve adoption of perennial farming systems on sufficient scale to influence water management without imposing a major economic and social burden on the wider community (Stoneham et al., 2003).

EverGraze is developing new perennial pasture and livestock systems that will substantially increase farm profit and simultaneously reduce groundwater recharge in catchments. The initial phase of the project used integrated bioeconomic and hydrological modelling. Hypothetical (typical) farms were designed at the biophysical level, while MIDAS (Morrison et al., 1986) and the Catchment Assessment Tool (CAT) (Beverly et al., 2005) were used to analyse management practices of the farms to ascertain which farming systems were most likely to increase profit and reduce recharge. Model results were validated and the farm systems designed for the experimental phase using model results in consultation with leading farmers and other experts.

The modelling indicated that in high rainfall landscapes there are several livestock-based farming systems with the potential to deliver significant profit and hydrological improvements. Importantly, modelling has shown that in some cases it is comparatively easy to reduce recharge through the use of perennial pastures; 
the challenge is to do this more profitably than current annual pasture systems. In other catchments, pastures alone may not result in the desired reduction in recharge, and woody perennials will be required in the landscape to achieve this goal. The challenge then is to incorporate these profitably into the farming system. Model results for farms in two high rainfall catchments in southern Australia are shown in Table 1.

Table 1. Predicted change (relative to a base 100\%) in production and water use from current to future livestock systems in the high rainfall zone (adapted from Masters et al., 2006)

\begin{tabular}{lccc}
\hline \multirow{2}{*}{ Item } & \multicolumn{3}{c}{ Farm system } \\
\cline { 2 - 4 } & $\begin{array}{c}\text { Merino } \\
\text { annuals }\end{array}$ & $\begin{array}{c}\text { Merino } \\
\text { perennials }\end{array}$ & $\begin{array}{c}\text { Meat Merino }^{1} \\
\text { perennials }\end{array}$ \\
\hline Profit, \% & 100 & $260-400$ & $400-800$ \\
Stocking rate, \% & 100 & $130-170$ & $150-175$ \\
Weaning, \% & 100 & $100-106$ & $106-170$ \\
Wool income, \$/ha & 100 & $130-170$ & $120-130$ \\
Sheep sales, \$/ha & 100 & $140-170$ & $450-660$ \\
Leakage below the root zone, $\mathrm{mm} /$ year & 100 & $70-90$ & $70-75$ \\
\hline
\end{tabular}

${ }^{1}$ surplus ewes not needed to maintain the flock are mated to a terminal sire

Data from the model suggest (see Masters et al., 2006 for more detail):

- perennial pasture-based sheep systems can be more profitable than annual pasture based systems because they allow a higher stocking rate,

- perennial pasture-based sheep systems will be more profitable if they utilize a meat Merino (using terminal sires mated to Merino ewes to produce first cross lambs) system,

- farm systems which include perennial pastures such as lucerne (Medicago sativa) and tall fescue (Festuca arundinacea) can substantially reduce leakage below the root zone,

- opportunities to further increase the profit from perennial pasture-based systems include altering lambing dates to better utilize the altered feedbase and increasing weaning percentages and lamb growth rates.

\section{FARM SYSTEMS RESEARCH IN EVERGRAZE}

While modelling indicated options to improve profit and improve natural resource outcomes, on-farm investigation of these options is required to validate the models and identify any limitations. Importantly, on farm investigation is also required to demonstrate the implementation and outcomes of the novel systems, which is an important prerequisite of adoption. 
EverGraze has established 'proof sites', where large scale ( $>50$ ha) experiments have been established to test the profit and natural resource management outcomes of novel systems. The novel systems tested vary from alterations to the feedbase through to alterations to the livestock systems grazing these. As an example, the proof site in Wagga Wagga, NSW, is testing whether delaying lambing time by two months ('Later Lambing') and joining 50\% of ewes to terminal sires makes more profitable use of a perennial pasture base (phalaris (Phalaris aquatica), lucerne and tall fescue) than a self-replacing Merino system. Furthermore, the site is testing whether the later lambing system is more profitable when grazing a system with $40 \%$ (as opposed to 20\%) lucerne. Each system comprises of 3 farmlets (replicates) of 5 ha. Preliminary data from 2006 are shown in Table 2. It should be noted that 2006 recorded substantially less rainfall than average for the region. A total of $252.2 \mathrm{~mm}$ was recorded at the research site, well below the long term averages recorded at the two nearest permanent weather stations (575 $\mathrm{mm}$ and $673 \mathrm{~mm}$ ).

The 2006 results reflect the drought conditions, with the treatment requiring the least supplementary feeding (due to lower stocking rate and earlier lambing time) being the most profitable. Modelling based on an average year indicated all systems should have minimal supplementary feed requirements. Hence Gross Margin 3 in Table 2 reflects the margin calculated without supplementary feeding costs. Gross Margin 4 reflects the margin had lambs in the later lambing treatments reached the target weaning weights which modelling indicated was possible in an average year. Hence in an average year we expect the later lambing systems to be far more profitable, although in an average year the lambs from the self-replacing Merino treatment may have reached greater weaning weights, increasing income and the gross margin from this system. Similarly, the analysis does not consider lamb price/kg to differ between Merino and crossbred lambs, which may result in gross margin data favouring systems producing crossbred lambs. Benchmarking data (David Sackett, personal communication) on the performance of self-replacing Merino flocks utilizing predominately annual pastures indicates an average Gross Margin based on 284 records over a nine year period (19982006) of $\$ 168 /$ ha at a comparable stocking rate to the self replacing Merino system in this study. The average Gross Margin (based on 14 records) from benchmarking data for a self replacing Merino system in 2006 was \$120/ha. The performance of the self-replacing Merino system on a perennial pasture base in this study suggests such a system can be more profitable in an extreme drought year than if the system had grazed an annual pasture base.

While the later lambing systems were less profitable in a drought year, in a more favourable year requiring less supplementary feeding and/or resulting in target weaning weights being achieved, the estimated grow margins for such outcomes (Table 2) indicate that systems incorporating crossbreeding and lambing later can increase Gross Margins further (to almost double that of a self-replacing Merino 
Table 2. Preliminary production and profit data (2006) for three farm systems

\begin{tabular}{|c|c|c|c|}
\hline \multirow{3}{*}{ Joining time } & \multicolumn{3}{|c|}{ Farm system } \\
\hline & $\begin{array}{c}\text { self-replacing } \\
\text { Merino }\end{array}$ & $\begin{array}{c}\text { later } \\
\text { lambing }\end{array}$ & $\begin{array}{l}\text { later lambing } \\
\text { - high lucerne }\end{array}$ \\
\hline & February & April & April \\
\hline Stocking rate, annual DSE/ha & 6.1 & 10.4 & 10.6 \\
\hline Stocking rate, August DSE/ha & 9.3 & 12.1 & 12.3 \\
\hline Phalaris, $\%$ of farm & 65 & 65 & 40 \\
\hline Lucerne, $\%$ of farm & 20 & 20 & 40 \\
\hline Fescue, $\%$ of farm & 15 & 15 & 10 \\
\hline Ewes joined to terminal, \% & 0 & 50 & 50 \\
\hline DSE grazing days, /ha & 1962 & 3377 & 3422 \\
\hline Supplementary grain fed, $\mathrm{kg} / \mathrm{ha}$ & 122 & 844 & 784 \\
\hline Supplementary hay fed, $\mathrm{kg} / \mathrm{ha}$ & 66 & 240 & 228 \\
\hline Supplementary feed costs, $\$ / \mathrm{ha}^{1}$ & $\$ 47$ & $\$ 271$ & $\$ 253$ \\
\hline Weaning, $\%$ of ewes joined & 118.3 & 97.5 & 102.5 \\
\hline Merino lamb weaning weight, $\mathrm{kg}$ & 30.6 & 19.1 & 19.4 \\
\hline Crossbred lamb weaning weight, $\mathrm{kg}$ & $\mathrm{n} / \mathrm{a}$ & 25.7 & 23.8 \\
\hline Merino lamb produced, $\mathrm{kg} / \mathrm{ha}$ & 139.8 & 67.6 & 82.2 \\
\hline Crossbred lamb produced, $\mathrm{kg} / \mathrm{ha}$ & $\mathrm{n} / \mathrm{a}$ & 101.0 & 90.3 \\
\hline Total lamb produced, $\mathrm{kg} / \mathrm{ha}$ & 139.8 & 168.6 & 172.5 \\
\hline Clean wool produced, $\mathrm{kg} / \mathrm{ha}$ & 12.4 & 24.9 & 25.3 \\
\hline Wool income ${ }^{2}, \$ A U D /$ ha & $\$ 133.92$ & $\$ 268.92$ & $\$ 273.24$ \\
\hline Lamb sales, \$AUD/ha ${ }^{3}$ & $\$ 174.25$ & $\$ 209.01$ & $\$ 213.21$ \\
\hline Gross Margin 1, \$AUD/ha ${ }^{4}$ & $\$ 198.68$ & $\$ 81.94$ & $\$ 105.45$ \\
\hline Gross Margin 2, \$AUD/ha ${ }^{5}$ & $\$ 208.08$ & $\$ 136.14$ & $\$ 151.05$ \\
\hline Gross Margin 3, \$AUD/ha ${ }^{6}$ & $\$ 245.68$ & $\$ 352.94$ & $\$ 358.45$ \\
\hline Gross Margin 4, \$AUD/ha ${ }^{7}$ & $\$ 245.68$ & $\$ 449.80$ & $\$ 468.53$ \\
\hline
\end{tabular}

DSE - dry sheep equivalent, where 1 DSE is a $45 \mathrm{~kg}$ Merino wether

${ }^{1}$ supplementary feed costed at $\$ 250 / \mathrm{T}$

${ }^{2}$ income based on a $19 \mu \mathrm{m}$ clean price of $1080 \mathrm{c} / \mathrm{kg}$

${ }^{3}$ income from lamb sales is based on $150 \mathrm{c} / \mathrm{kg} \mathrm{BW}$. Only Merino ewe lambs excess to replacement requirements ( $20 \%$ of ewe flock) sold

${ }^{4}$ estimates are based on income from wool and lamb sales less costs of $\$ 16.20 /$ ewe and supplementary feed costs, but does not include fertilizer costs etc. (as these are the same per ha for each system)

${ }^{5}$ estimates based on supplementary feed costs of $\$ 200 / \mathrm{T}$

${ }^{6}$ estimates based on no supplementary feed required

${ }^{7}$ estimates based on no supplementary feed required and later lambs reaching target weights of $30 \mathrm{~kg}$ (Merino) and $35 \mathrm{~kg}$ (crossbred) at weaning

system), broadly supporting the model data (Table 1). Furthermore, the system including $40 \%$ lucerne returned a greater Gross Margin in a drought year than the same system based on $20 \%$ lucerne (Table 1). This is significant, given lucerne has 
the greatest potential to reduce deep drainage, as incorporation of more lucerne in the farm system may lead to significant improvements in both profit and environmental outcomes. Data from 2007 and 2008 are required in order to validate the model over a range of seasons and identify limitations to the model.

\section{CONCLUSIONS}

Livestock offer practical options for the profitable expansion of perennial plants within the higher rainfall areas of southern Australia to ameliorate increases in salinity and other environmental problems.

Integrated bio-economic and hydrological modelling has been critical in designing systems that can lead to improvements in both profit and environmental outcomes. Modelling has also been useful in identifying knowledge gaps requiring immediate component research. On-ground studies are currently underway to determine the best mix of livestock genetics, management and pastures to optimize profits and improve environmental outcomes.

\section{ACKNOWLEDGEMENTS}

EverGraze is a CRC Salinity, Meat and Livestock Australia and Australian Wool Innovation research and delivery partnership collaborating with Catchment Management Authorities, the Murrumbidgee CMA involved with the Wagga site. The skilled technical support of John Broster is gratefully acknowledged, as is the provision of benchmarking data by Holmes and Sackett and Associates.

\section{REFERENCES}

Beverly C., Bari M., Christy B., Hocking M., Smettem K., 2005. Salinity impacts from land use change: comparison between a rapid assessment approach and a detailed modelling framework. Aust. J. Exp. Agr. 45, 1415-1424

Macfarlane D.J., George R.J., Cacceta P.A., 2004. The extent and potential area of salt-affected land in Western Australia estimated using remote sensing digital terrain models. In: S. Dogramaci, A. Watehouse (Editors). Engineering Salinity Solutions, $1^{\text {st }}$ National Salinity Engineering Conference. Institution of Engineers, Australia Perth, pp. 55-60

Masters D., Edwards N., Sillence M., Avery A., Revell D., Friend M., Sanford P., Saul G., Beverly C., Young J., 2006. The role of livestock in the management of dryland salinity. Aust. J. Exp. Agr. 46, 733-741

Morrison D.A., Kingwell R.S., Pannell D.J., Ewing M.A., 1986. A mathematical programming model of a crop-livestock farm system. Agr. Syst. 20, 243-268

Stoneham G., Eigenraam M., Ridley A., Barr N., 2003. The application of sustainability indicators to Australian Agriculture: an overview. Aust. J. Exp. Agr. 43, 195-203 